\title{
Effects of continuous cropping and NPK fertilizer on growth and yield of cowpea (Vigna unguiculata (I) Walp) grown on soils from different management systems
}

\section{Efectos del cultivo continuo y del fertilizante NPK sobre el crecimiento y rendimiento de cowpea (Vigna unguiculata (I) walp) cultivada en suelos de diferentes sistemas de gestión}

\author{
*Anthony Uhunomwan Omoregie ${ }^{1}, \mathrm{~K}$. Areghan ${ }^{1}$ and Sunday Ebonka Nwajei ${ }^{1}$
}

Department of Crop Science, Ambrose Alli University, Ekpoma, Nigeria.

Email: uhunsregie@aauekpoma.edu.ng and sodje4real10@gamil.com

*Corresponding author: uhunsregie@aauekpoma.edu.ng +2348053262862

\begin{abstract}
Studies were conducted to investigate the effect of continuous cropping and NPK fertilizer on the growth and yield of cowpea (Vigna unguiculata (L) Walp) grown on soils from different management systems. The investigations were carried out in two parts. The first dealt with the effect of continuous cropping while the other focused on the effect of NPK fertilizer on cowpea. Representative soil samples were obtained at 0-15 cm depth from land which had been continuously cropped, under forest tree fallow, and secondary bush fallow. These were bulked, processed, and analyzed. Six (6) kg of each type of soil were weighed into $25 \times 22 \mathrm{~cm}$ polybag of 500 gauge. The continuous cropping experiment involved three cropping cycles of 35 days each of cowpea on the same soils from 3 cropping systems. In the second experiment, a $2 \times 3$ factorial involving 2 levels of fertilizers $(0,40 \mathrm{~kg} \mathrm{NPK} / \mathrm{ha})$ and 3 sources of soil were carried out to test their effects on cowpea. The growth parameters measured were plant height, number of leaves/plant and number of branches/plant. Number of nodules/plant, number of pods/plant, dry matter and grain yield were also estimated. Successive cropping of soils significantly reduced cowpea growth. Cowpea plants grown on soils from continuously cropped land had the least growth performance. Number of nodules/plant increased with successive cropping. Higher dry matter yield was obtained from the continuously cropped land. A significant $(r=+0.55)$ positive correlation was found between soil $P$ and dry matter yield of cowpea. NPK fertilization had only significant effect on plant height at 10 WAP but not on other growth parameters measured. The highest grain yield was obtained from unfertilized secondary bush fallow soil. Sources of soil (soil management system) had significant effect on some of the agronomic characters of cowpea.
\end{abstract}

Keywords: Continuous cropping, NPK, cowpea, management systems.

\section{RESUMEN}

Se realizaron estudios para investigar el efecto del cultivo continuo y el fertilizante NPK en el crecimiento y rendimiento del caupí (Vigna unguiculata (L) Walp) cultivado en suelos de diferentes sistemas de manejo. Las investigaciones se llevaron a cabo en dos partes. El primero abordó el efecto del cultivo continuo, mientras que el otro se centró en el efecto del fertilizante 
NPK en el caupí. Se obtuvieron muestras representativas de suelo a $0-15 \mathrm{~cm}$ de profundidad de tierras que habían sido cultivadas continuamente, bajo barbecho de árboles forestales y barbecho arbustivo secundario. Estos fueron agrupados, procesados y analizados. Se pesaron seis (6) $\mathrm{kg}$ de cada tipo de suelo en bolsas de polietileno de $25 \times 22 \mathrm{~cm}$ de calibre 500 . El experimento de cultivo continuo involucró tres ciclos de cultivo de 35 días cada uno de caupí en los mismos suelos de 3 sistemas de cultivo. En el segundo experimento, se llevó a cabo un factorial $2 \times 3$ con 2 niveles de fertilizantes ( $0,40 \mathrm{~kg} \mathrm{NPK} / \mathrm{ha}$ ) y 3 fuentes de suelo para probar sus efectos sobre el caupí. Los parámetros de crecimiento medidos fueron altura de planta, número de hojas / planta y número de ramas / planta. También se estimó el número de nódulos / planta, número de vainas / planta, materia seca y rendimiento de grano. El cultivo sucesivo de suelos redujo significativamente el crecimiento del caupí. Las plantas de caupí cultivadas en suelos de tierras continuamente cultivadas tuvieron el menor rendimiento de crecimiento. El número de nódulos / planta aumentó con cultivos sucesivos. Se obtuvo un mayor rendimiento de materia seca de la tierra continuamente cultivada. Se encontró una correlación positiva significativa $(r=+0.55)$ entre el $P$ del suelo y el rendimiento de materia seca del caupí. La fertilización con NPK solo tuvo un efecto significativo en la altura de la planta a 10 WAP, pero no en otros parámetros de crecimiento medidos. El mayor rendimiento de grano se obtuvo de un suelo de barbecho arbustivo secundario no fertilizado. Las fuentes del suelo (sistema de manejo del suelo) tuvieron un efecto significativo sobre algunas de las características agronómicas del caupí.

Palabras clave: cultivo continuo, NPK, caupí, sistemas de manejo.

\section{ABSTRACT}

Studies were conducted to investigate the effect of continuous cropping and NPK fertilizer on the growth and yield of cowpea (Vigna unguiculata (L) Walp) grown on soils from different management systems. The investigations were carried out in two parts. The first dealt with the effect of continuous cropping while the other focused on the effect of NPK fertilizer on cowpea. Representative soil samples were obtained at 0-15 cm depth from land which had been continuously cropped, under forest tree fallow, and secondary bush fallow. These were bulked, processed, and analyzed. Six (6) kg of each type of soil were weighed into $25 \times 22 \mathrm{~cm}$ polybag of 500 gauge. The continuous cropping experiment involved three cropping cycles of 35 days each of cowpea on the same soils from 3 cropping systems. In the second experiment, a $2 \times 3$ factorial involving 2 levels of fertilizers $(0,40 \mathrm{~kg} \mathrm{NPK} / \mathrm{ha}$ ) and 3 sources of soil were carried out to test their effects on cowpea. The growth parameters measured were plant height, number of leaves/plant and number of branches/plant. Number of nodules/plant, number of pods/plant, dry matter and grain yield were also estimated. Successive cropping of soils significantly reduced cowpea growth. Cowpea plants grown on soils from continuously cropped land had the least growth performance. Number of nodules/plant increased with successive cropping. Higher dry matter yield was obtained from the continuously cropped land. A significant $(r=+0.55)$ positive correlation was found between soil $P$ and dry matter yield of cowpea. NPK fertilization had only significant effect on plant height at 10 WAP but not on other growth parameters measured. The highest grain yield was obtained from unfertilized secondary bush fallow soil. Sources of soil (soil management system) had significant effect on some of the agronomic characters of cowpea.

Keywords: Continuous cropping, NPK, cowpea, management systems, yield

\section{INTRODUCTION}

Soil support plants in varying degrees of efficiency and their productive capacities depend on their nutrient status as well as their management system. Nigerian soils are very 
delicate and suffer a decline in physical and chemical properties rather rapidly after cultivation. One of the ways of restoring soils is through fallow (Oyeyiola and Omueti, 2016.). Nutrients are gradually accumulated during the fallow period and provide alternative to fertilization (Nkaa et al., 2014.). Although fallow is one sure way of ensuring nutrient recycling, however, population pressure on the land has shortened the fallow period necessary for regeneration of forest or bush (Ramos et al., 2003).

The direct effect of short fallow is continuous cropping of land. Studies by Hasan et al. (2010) and IITA (2003) showed that soil fertility declined after cropping and the degree of decline became greater with each successive cropping.

This study was undertaken to compare the productivity of soils under different management systems using cowpea as a test crop.

\section{MATERIALS AND METHODS}

The study involved two experiments. The first part dealt with the effect of continuous cropping while the second focused on the effect of NPK fertilizer on the growth and yield of cowpea.

A location with adjacent areas having forest trees (under tree fallow), secondary bush (bush fallow) and continuously cropped (under cropping) was identified at Iruekpen, Ekpoma, Edo State, Nigeria located between Latitude $6^{\circ} 18^{1} \mathrm{~N}$ and Latitude $6^{\circ} 46^{1} \mathrm{~N}$; and Longitude $6^{\circ}$ and $6^{\circ} 4^{1} \mathrm{E}$ ).

Representative soil samples $(0-15 \mathrm{~cm})$ were obtained from the three management systems and bulked accordingly. The soil samples were processed and passed through $2 \mathrm{~mm}$ mesh sieve. Sub-samples were analyzed for physico-chemical properties according to the methods described by IITA (1979).

Experiment 1: Effect of continuous cropping on growth and dry matter yield of cowpea. Six (6) $\mathrm{kg}$ of each soil type was weighed into polybags of dimension $25 \times 22 \mathrm{~cm}$. These were completely randomized with 4 replicates. The test crop was cowpea, cultivar IT870-941-1 Brown obtained from IITA, Ibadan. Each polybag had one plant after thinning. The polybags were spaced at $60 \times 30 \mathrm{~cm}$ between and within the rows. These were kept weed-free by hand pulling the weeds. The cowpea plants were rain-fed and watered during rainless days. At 35 days after planting (DAP), whole plants were harvested. Three cycles of planting and harvesting were done. Plant height, number of leaves, stem girth, number of nodules, root length and dry matter were estimated using standard methods.

Experiment 2: Effect of NPK fertilizer on the growth and yield of cowpea.

Six (6) $\mathrm{kg}$ of each type of soil was also filled into polybags of the same dimension in Experiment 1. A $2 \times 3$ factorial involving 2 levels of fertilizer $(0,40 \mathrm{~kg} \mathrm{NPK} / \mathrm{ha})$ and 3 sources of soil were laid out in a complete randomized design. Each polybag had 1 plant. The same agronomic practices applied as in Experiment I.

Plant height, number of leaves, number of pods, number of nodules, branches/plant, number of pods, dry matter and grain yield were estimated.

Data analysis: The analysis of variance (ANOVA) used for growth and yield data were computed using the Statistical Analysis System (SAS) package version 9.0 (2002) and the means separated using Duncan's Multiple Range Test (DMRT) at 0.05 level of probability.

\section{RESULTS AND DISCUSSION}

Table 1 shows the physico-chemical properties of the experimental soils. These soils had comparable properties, low $\mathrm{pH}\left(\mathrm{H}_{2} \mathrm{O}\right)$, low total $\mathrm{N}$ and clay. The soils were high in sand and available P. Experiment 1: Effect of continuous cropping on growth and dry matter yield of cowpea. 
Table 1: Physical and Chemical Properties of Experimental Soils

\section{Exchangeable}

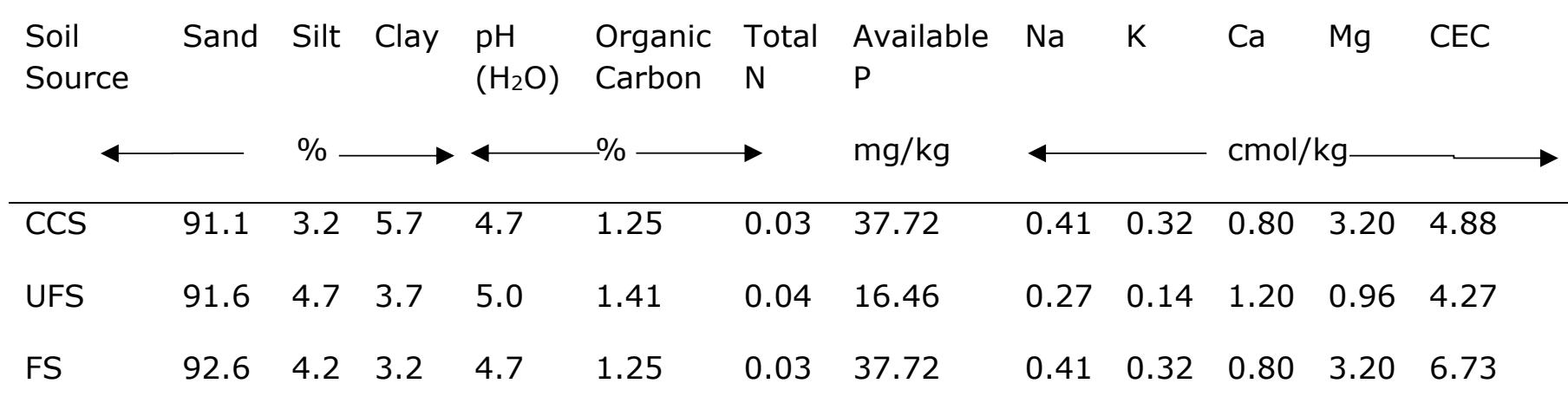

CCS = Continuously Cropped Soil; UFS = Under Bush Fallow; FS = Forest Soil

The effect of continuous cropping of the soils on growth and yield of cowpea are presented in Table 2. It was observed that successive cropping of the various soils generally led to a reduction in the growth of cowpea. The significant effect of continuous cropping was pronounced in plants grown on soils from forest tree fallow, particularly for plant height, number of leaves, stem girth and length of root.

Table 2: Effect of continuous cropping on growth and yield of cowpea

$\begin{array}{lllccc}\text { Plant height }(\mathrm{cm}) & \text { No of leaves/plant } & \text { Stem girth }(\mathrm{cm}) & \begin{array}{c}\text { No of } \\ \text { Nodules/plant }\end{array} & \begin{array}{c}\text { Root length } \\ (\mathrm{cm})\end{array} & \begin{array}{c}\text { Dry matter } \\ \text { yield }(\mathrm{g} / \mathrm{pot})\end{array}\end{array}$

Continuously Cropped Soil

$1^{\text {st }}$ cropping

$2^{\text {nd }}$ cropping

$3^{\text {rd }}$ cropping

Mean

Under fallow Soil

$1^{\text {st }}$ cropping

$2^{\text {nd }}$ cropping

$3^{\text {rd }}$ cropping

Mean

Forest Cropped Soil

$1^{\text {st }}$ cropping

$2^{\text {nd }}$ cropping

$3^{\text {rd }}$ cropping

Mean $15.63^{a}$

$13.25^{\mathrm{a}}$

$11.13^{a}$

$13.34^{\mathrm{a}}$

$18.75^{a}$

$15.63^{b}$

$12.57^{c}$

15.57

$18.50^{\mathrm{a}}$

$14.25^{b}$

$11.13^{c}$

14.63 $8.25^{a}$

$5.25^{\mathrm{a}}$

$5.50^{\mathrm{a}}$

$6.33^{a}$

$11.75^{\mathrm{a}}$

$6.75^{b}$

$5.00^{\mathrm{bc}}$

7.83

$15.25^{a}$

$4.75^{\mathrm{b}}$

$4.50^{\mathrm{bc}}$

8.17 $1.65^{\mathrm{a}}$

$1.38^{\mathrm{a}}$

$1.33^{\mathrm{a}}$

$1.45^{\mathrm{a}}$

$1.65^{\mathrm{a}}$

$1.55^{\mathrm{a}}$

$1.48^{\mathrm{a}}$

$1.56^{\mathrm{a}}$

$1.93^{\mathrm{a}}$

$1.50^{\mathrm{b}}$

$1.45^{\mathrm{bc}}$

1.62 $33.50^{a}$

$30.25^{\mathrm{a}}$

$39.75^{\mathrm{a}}$

$34.57^{a}$

$40.00^{a}$

$42.00^{\mathrm{a}}$

$47.25^{a}$

$43.08^{\mathrm{a}}$

$16.50^{\mathrm{a}}$

$32.75^{\mathrm{a}}$

$25.08^{a}$ $25.38^{\mathrm{a}}$

$24.63^{a}$

$27.13^{a}$

$26.13^{a}$

$31.63^{a}$

$28.20^{a}$

$31.99^{a}$

$20.25^{a}$

$3.72^{\mathrm{a}}$

$5.18^{\mathrm{a}}$

$4.16^{\mathrm{a}}$

$4.15^{\mathrm{a}}$

$20.99^{a}$

$25.71^{\mathrm{a}}$ $3.12^{\mathrm{a}}$

$3.05^{\mathrm{a}}$

$2.51^{\mathrm{a}}$

$2.89^{a}$

Figures in the column bearing same letter do not differ significantly $(p<0.05)$. 
The soil from the continuously cropped land had relatively lower growth than other sources of soils. Highest dry matter yield $(4.15 \mathrm{~g} / \mathrm{pot})$ was obtained from soil under bush fallow. Unlike the decrease observed in growth parameters with successive cropping, number of nodules/plant increased with cropping the soils with cowpea.

The decline in yields resulting from cropping systems which involves monoculture of plants has been reported by IITA (2003) as observed in the present study.

Experiment 2: Effect of NPK fertilizer on the growth and yield of cowpea. Sources of soil/management system and fertilizer had no significant effect at $5 \%$ level of significance on the number of leaves, stem girth and number of branches/plant. However, plant height was significantly affected by source of soil and fertilizer (Table 3). Unfertilized bush fallow soil had the highest DM and grain yields (Table 4). NPK fertilizer reduced the yield parameters measured in some instances.

The use of inorganic fertilizers in cowpea is widespread in large scale farms and research stations. Legumes, even when suitably inoculated, will not grow well unless soil nutrients are available (Emmanuel, 2005). In the soils used for this study, nutrients levels were generally low. So, a high response was expected but this was not the case. This may indicate that the level of nutrients in the soils were enough for the growth of cowpea. Abayomi et al. (2008), Ayodele and Oso (2014) reported NPK fertilizer increased the seed yield of cowpea. Cowpeas are naturally well nodulated and can fix adequate $\mathrm{N}$ to meet its requirement without addition to the soil. Yusuf et al. (2009) and Sanginga et al. (2002) reported high amount of $\mathrm{N}_{2}$ fixed due to number of days required to maturity.

Table 3: Effect of source of soil and fertilizer on growth of cowpea (10 WAP)

\begin{tabular}{lcccc}
\hline Treatments & Plant height $(\mathrm{cm})$ & No of leaves/plant & Stem girth $(\mathrm{cm})$ & No of branches/plant \\
\hline$(\mathrm{CCU})$ & $24.63^{\mathrm{c}}$ & $26.50^{\mathrm{a}}$ & $2.58^{\mathrm{a}}$ & $2.75^{\mathrm{a}}$ \\
$(\mathrm{CCF})$ & $25.50^{\mathrm{bc}}$ & $30.75^{\mathrm{a}}$ & $3.83^{\mathrm{a}}$ & $3.75^{\mathrm{a}}$ \\
$(\mathrm{FSU})$ & $35.20^{\mathrm{ab}}$ & $41.50^{\mathrm{a}}$ & $3.03^{\mathrm{a}}$ & $4.75^{\mathrm{a}}$ \\
$(\mathrm{FSF})$ & $4.88^{\mathrm{a}}$ & $33.00^{\mathrm{a}}$ & $3.18^{\mathrm{a}}$ & $4.75^{\mathrm{a}}$ \\
$(\mathrm{FU})$ & $35.75^{\mathrm{a}}$ & $43.75^{\mathrm{a}}$ & $3.15^{\mathrm{a}}$ & $3.75^{\mathrm{a}}$ \\
$(\mathrm{FF})$ & $36.38^{\mathrm{a}}$ & $38.50^{\mathrm{a}}$ & $3.35^{\mathrm{a}}$ & $4.25^{\mathrm{a}}$ \\
\hline
\end{tabular}

All figures bearing same letter in column are not significantly different $(p<0.05)$

$\mathrm{CCU}=$ Continuously Cropped (Unfertilized soil); CCF = Continuously Cropped (Fertilized soil); FSU = Forest Soil Unfertilized; FSF = Forest Soil Fertilized; FU = Fallow Soil Unfertilized; FSF = Fallow Soil Fertilized.

Table 4: Effect of source of soil and fertilizer on the yield of cowpea (Vigna unguiculata L Walp) 
Dry matter

\begin{tabular}{lccccc}
\hline Treatments & Shoot $(\mathrm{g})$ & Root $(\mathrm{g})$ & Grain yield $(\mathrm{g})$ & No of nodules/plant & No of pods/plant \\
$(\mathrm{CCU})$ & $33.72^{\mathrm{b}}$ & $4.37^{\mathrm{b}}$ & $17.70^{\mathrm{ab}}$ & $23.50^{\mathrm{c}}$ & $16.50^{\mathrm{b}}$ \\
$(\mathrm{CCF})$ & $24.31^{\mathrm{b}}$ & $4.83^{\mathrm{b}}$ & $12.32^{\mathrm{b}}$ & $26.75^{\mathrm{c}}$ & $16.75^{\mathrm{b}}$ \\
$(\mathrm{FSU})$ & $34.49^{\mathrm{b}}$ & $6.30^{\mathrm{b}}$ & $14.52^{\mathrm{b}}$ & $94.25^{\mathrm{a}}$ & $12.00^{\mathrm{b}}$ \\
$(\mathrm{FSF})$ & $26.85^{\mathrm{b}}$ & $7.45^{\mathrm{b}}$ & $20.20^{\mathrm{a}}$ & $94.50^{\mathrm{a}}$ & $21.75^{\mathrm{a}}$ \\
$(\mathrm{FU})$ & $59.35^{\mathrm{a}}$ & $11.57^{\mathrm{a}}$ & $26.44^{\mathrm{a}}$ & $79.25^{\mathrm{a}}$ & $18.50^{\mathrm{ab}}$ \\
$(\mathrm{FF})$ & $23.18^{\mathrm{b}}$ & $6.66^{\mathrm{b}}$ & $23.22^{\mathrm{a}}$ & $47.00^{\mathrm{a}}$ & $25.50^{\mathrm{a}}$
\end{tabular}

* Figures bearing same letter in the column do not differ significantly $(p<0.05)$

The use of inorganic fertilizers in cowpea is widespread in large scale farms and research stations. Legumes, even when suitably inoculated, will not grow well unless soil nutrients are available. In the soils used for this study, nutrients level were generally low. So, a high response was expected but this was not the case. This may indicate that the level of nutrients in the soils were enough for the growth of cowpea. Abayomi et al. (2008), Ayodele and Oso (2014) reported NPK fertilizer increased the seed yield of cowpea. Cowpeas are naturally well nodulated and can fix adequate $\mathrm{N}$ to meet its requirement without addition to the soil. Yusuf et al. (2009), Sanginga et al. (2002) reported high amount of $\mathrm{N}_{2}$ fixed due to number of days required to maturity.

As conclusion, the physico-chemical properties of adjacent sites from which the soils were obtained did not show much difference in the composition. Continuous cropping of the soils resulted in declined growth and yield of cowpea. NPK fertilizer had significant effect on plants height at 10WAP.

\section{REFERENCES}

Abayomi, Y.A., Ajibade, T.V., Samuel, O.F. and Sa'adudeen, B.F. 2008. Growth and yield responses of cowpea genotype to nitrogen fertilizer (N.P.K) application in the Southern Guinea Savanna zone of Nigeria. Asian Journal of Plant Science 7(2): 170-176.

Ayodele, O.J. and Oso, A.A. 2014. Cowpea responses to phosphorus fertilizer application in Ado-Ekiti, South West Nigeria. Journal of Applied Science and Agriculture 9(2): 485489.

Emmanuel, O.C. 2005. Growth and yield response of cowpea to NPK fertilizer and rhizobia inoculation in the Guinea and Sudan Savanna zones of Ghana. Ph.D thesis submitted to the Department of Crop and Soil, University of Agriculture and Technology, Kumasi Ghana1-195 pp.

Hasan, M.R., Akbar, M.A., Khandaker, Z.H. and Rahman, M.M. 2010. Effect of nitrogen fertilizer on yield contributing character, biomass yield and nutritive value of cowpea forage. Bang. J. of Anim. Sci. 39 (1 and 2): 83-88.

IITA 1979. Selected methods for soil and plant analysis. Manual series No.1. International Institute of Tropical Agriculture, Ibadan, Nigeria. 70 pp 
IITA 2003. Crop and farming system. International Institute of Tropical Agriculture, Ibadan, Nigeria, Africa. 24-27.pp.

Nkaa, F.A., Nwokeocha, O.W. and Ihuoma, O. 2014. Effect of phosphorus fertilizer on growth and yield of cowpea (Vigna unguiculata). Journal of Pharmacy and Biological Science. 9(5): 74-82.

Oyeyiola, Y.B. and Omueti, J.A.I. 2016. Phosphorus uptake and use efficiency by cowpea in phosphocompost and chemical fertilizer treated nutrient degraded acid soils. Agricultureal Research and Technology. Open Access Journal 1 (15): 1-8.

Ramos, M.L.G., Parsons, R., Sprent, J.I. and James, E.K. 2003. Effect of water stress on nitrogen fixation and nodule structure of common bean. Brasilia 38: 339-347.

Sanginga, N., Okogun, J., Vanlauwe, B. and Dashiell, K. 2002. The contribution of nitrogen by promiscuous soybean to maize based cropping in the moist Savanna of Nigeria. Plant and Soil 220:119-128.

Statitical Analysis System. (2002). SAS user's guide: Statistics version 9.0 Cary, NC, USA: SAS Institute Inc., 2002.

Yusuf, A.A., Iwuafor, E.N.O., Abaidoo, R.C. Olufajo, O.O. and Sanginga, N. 2009. Grain legume rotation benefit to maize in the northern Guinea Savanna of Nigeria: fixed-nitrogen versus other rotation effects. Nutrient Cycle Agroecosyst 84: 129-139.

Received: $20^{\text {th }}$ November 2019; Accepted: $27^{\text {th }}$ August 2020; First distribution: $17^{\text {th }}$ September 2020. 